\title{
ASESMEN AUTENTIK DALAM PEMBELAJARAN BAHASA
}

\author{
Siti Zahrok
}

\begin{abstract}
Abstrak
Asesmen autentik adalah suatu penilaian belajar yang merujuk pada situasi atau konteks dunia "nyata" yang memerlukan berbagai macam pendekatan untuk memecahkan masalah yang memberikan kemungkinan bahwa satu masalah bisa mempunyai lebih dari satu macam pemecahan. Dengan kata lain, asesmen autentik memonitor dan mengukur kemampuan siswa dalam bermacam-macam kemungkinan pemecahan masalah yang dihadapi dalam situasi atau konteks dunia nyata.

Asesmen autentik meliputi asesmen kinerja (Performance Assessment), asesmen portofolio (Portfolio Assesment), dan asesmen diri siswa (Student Self Assessment). Asesmen kinerja dikembangkan untuk menilai kemampuan siswa dalam mendemonstrasikan pengetahuan dan keterampilannya pada berbagai situasi nyata dan konteks tertentu. Asesmen portofolio merupakan salah satu cara penilaian terhadap kinerja dan hasil kerja, sehingga segala aktivitas yang dilakukan bisa dihargai dengan nilai. Asesmen diri siswa dapat meningkatkan keterlibatan siswa langsung dalam pembelajaran dan mengintegrasikan kemampuan kognitif dengan motivasi dan sikap terhadap pembelajaran.
\end{abstract}

Kata Kunci: Asesmen autentik, konsep dasar, dan jenis asesmen autentik

Istilah penilaian atau dalam bahasa Inggris dikenal evaluation atau assessment, bukan merupakan istilah baru bagi insan yang bergerak pada lapangan pendidikan dan pengajaran. Pada akhir suatu program pendidikan dan pengajaran, pada umumnya diadakan asesmen atau penilaian. Tujuan utama penggunaan asesmen dalam pembelajaran (classroom assessment) adalah membantu guru dan siswa dalam mengambil keputusan profesional untuk memperbaiki pembelajaran. Menurut Popham (1995:4-13) asesmen bertujuan untuk: (1) mendiagnosis kelebihan dan kelemahan siswa dalam belajar, (2) memonitor kemajuan siswa, (3) menentukan jenjang kemampuan siswa, (4) menentukan efektivitas pembelajaran, (5) memengaruhi persepsi publik tentang efektivitas pembelajaran, (6) mengevaluasi kinerja guru kelas, (7) mengklarifikasi tujuan pembelajaran yang dirancang guru. 
Lebih dari beberapa dekade, dunia pendidikan selalu berusaha untuk mencari suatu alternatif yang lebih baik untuk melakukan asesmen dalam pendidikan. Format asesmen selama ini banyak digunakan untuk ujian (ulangan), baik ujian yang bersifat standar maupun asesmen dalam kelas, seperti ujian nasional atau ujian akhir sekolah, ujian tengah semester, ujian kenaikan kelas, maupun ulangan harian, adalah berbentuk pilihan ganda. Hal ini seolah sudah menjadi program utama dalam dunia pendidikan. Beberapa pakar pendidikan sempat mempertanyakan manfaat tipe ini dalam mengukur ketercapaian siswa dalam pembelajaran, sehingga mereka mencari alternatif untuk pengembangan format asesmen, terutama yang mampu mencerminkan aktivitas instruksional dalam kelas.

Sumarna Surapranata, Muhammad Hatta (2004) menyatakan dewasa ini, di beberapa negara termasuk Indonesia, penggunaan tes sebagai salah satu alat penilaian sedikit demi sedikit bergeser pada penggunaan asesmen bentuk lain (alternative assesment). Salah satu sebab karena sebagian guru kurang memahami asesmen secara mendalam. Kebanyakan guru tidak memiliki latar belakang pendidikan formal secara khusus dalam penilaian pendidikan.

Stiggin (1991) mengatakan bahwa asesmen alternatif (alternative assessment) mencakup beberapa metode yang mampu mengemukakan apa yang telah diketahui dan dicapai siswa untuk menunjukkan perkembangan/ kemajuan siswa dan menginformasikan kegiatan instruksional dalam kelas. Asesmen alternatif juga menjadi sebuah alternatif bagi bentuk (format) ujian tradisional, yakni ujian berupa pilihan ganda (multiple choice test). Asesmen alternatif ini pulalah yang kemudian dapat dikatakan autentik, karena mengacu pada kegiatan yang mampu mewakili setting di dalam kelas dan sekaligus dalam dunia nyata (di luar kelas). O’Malley dan Pierce (1996: 2) menggunakan istilah 'asesmen autentik' untuk menggambarkan suatu format asesmen ganda yang konsisten dengan tujuan yang hendak dicapai di dalam kelas, kurikulum, dan juga tujuan instruksional.

Asesmen autentik banyak diminati karena dua alasan mendasar, yaitu bahwa prosedur asesmen yang telah ada sebelumnya tidak mampu mengases 
(menilai) tingkat keberhasilan siswa, dan para guru mengalami kesulitan dalam menggunakan informasi (tentang siswa) yang telah diperoleh untuk perencanaan tujuan instruksional. Para pendidik juga mempertanyakan keberhasilan ujian berbentuk 'pilihan ganda', karena format ujian 'pilihan ganda' tidak mampu menilai secara menyeluruh terhadap ketrampilan berpikir tingkat yang lebih tinggi (higher- order thinking skills) yang diaggap penting dalam kurikulum saat ini. Juga, menurut Resnick dan Klopfer (1989), tipe- tipe ujian 'pilihan ganda' ini tidak dapat mencerminkan peningkatan pemahaman dalam proses belajar siswa. O’Malley dan Pierce (1996) menambahkan, bahwa ilmu pengetahuan dan keterampilan- keterampilan yang dibutuhkan siswa yang bersifat efektif dan fungsional dalam masyarakat majemuk dan berbasis teknologi di masa depan, tidak cukup hanya direpresentasikan dalam ujian berbentuk 'pilihan ganda'. Karena itulah diperlukan format yang tepat untuk menilai siswa dan memonitor kemajuannya dalam proses pembelajaran.

Agar hasil belajar dapat diungkap secara menyeluruh, maka selain digunakan alat ukur tes objektif dan subjektif perlu dilengkapi dengan alat ukur yang dapat mengetahui kemampuan siswa dari aspek kerja ilmiah (keterampilan dan sikap ilmiah) dan seberapa baik siswa dapat menerapkan informasi pengetahuan yang diperolehnya. Alat penilaian yang diasumsikan dapat memenuhi hal tersebut antara lain adalah dengan penilaian autentik yang meliputi jenis penilaian kinerja (performance assessment), penilaian karya (product assessment), dan penilaian portofolio. Asesmen otentik adalah praktik asesmen yang secara langsung dan bermakna dalam arti apa yang diases adalah merupakan sesuatu yang benar-benar diperlukan dalam kehidupan nyata siswa

\section{Konsep Dasar Asesmen : Pengertian Asesmen}

Asesmen dalam pembelajaran adalah suatu proses atau upaya formal pengumpulan informasi yang berkaitan dengan variabel-variabel penting pembelajaran sebagai bahan dalam pengambilan keputusan oleh guru untuk memperbaiki proses dan hasil belajar siswa (Herman et al., 1992:95; Popham, 1995:3). Variabel-variabel penting yang dimaksud sekurang-kurangya meliputi 
pengetahuan, pemahaman, keterampilan dan sikap siswa dalam pembelajaran yang diperoleh guru dengan berbagai metode dan prosedur baik formal maupun informal, sebagaimana dikemukakan oleh Corner (1991: 2--3)

A general term enhancing all methods customarily used to appraise performance of individual pupil or group. It may refer to a broad appraisal including many sources of evidence and many aspects of pupil's knowledge, understanding, skills and attitudes; an assessment instrument may be any method and procedure, formal or in-formal, for producing information about pupil....

Pengertian asesmen dalam berbagai literatur asing tersebut di atas selaras dengan makna penilaian yang digariskan dalam Buku Pedoman Penilaian pada kurikulum pendidikan dasar. Dalam buku tersebut tertulis bahwa, penilaian adalah suatu kegiatan yang dilakukan oleh guru untuk memberikan berbagai informasi secara berkesinambungan dan menyeluruh tentang proses dan hasil belajar yang telah dicapai (Depdikbud, 1994:3). Ada pun yang dimaksud dengan asesmen alternatif adalah segala jenis bentuk asesmen diluar asesmen konvensional (selected respon test dan paper-pencil test) yang lebih autentik dan signifikan mengungkap secara langsung proses dan hasil belajar siswa. Herman (1997) memberikan semboyan khusus bagi asesmen alternatif dengan ungkapan "What You Get is What You Assess" (WYGWYA). Dalam beberapa literatur, asesmen alternatif ini kadang-kadang disebut juga asesmen autentik (authentic assessment), asesmen portofolio (portfolio assessment) atau asesmen kinerja (performsnce assessment). (Herman,1997:197-198; Niemi,1997:243; Harlen, 1992:6; Marzano, et al.,1993:13; Popham, 1995:142)

\section{Pengertian Asesmen Autentik}

Penilaian merupakan suatu kegiatan yang tidak mungkin dipisahkan dari kegiatan pendidikan dan pengajaran secara unum Semua kegiatan pendidikan yang dilakukan selalu diikuti atau disertai dengan kegiatan penilaian. (Burhan Nurgiyantoro, 2001: 3). Pendapat ini juga sesuai dengan apa yang dinyatakan oleh 
Jonathan Mueller dalam http://jonathan.mueller.faculty. noctrl.edu/toolbox/ examples. htm

Assessment is an integral part of instruction and learning. When assessment is located in the classroom, it has the most immediate value. This is why assessment cannot be separated from instruction. With good assessment we can improve instruction, and with good instruction we can improve the achievement of all students.

Asesmen autentik adalah suatu penilaian belajar yang merujuk pada situasi atau konteks dunia "nyata" yang memerlukan berbagai macam pendekatan untuk memecahkan masalah yang memberikan kemungkinan bahwa satu masalah bisa mempunyai lebih dari satu macam pemecahan. Dengan kata lain, asesmen autentik memonitor dan mengukur kemampuan siswa dalam bermacam-macam kemungkinan pemecahan masalah yang dihadapi dalam situasi atau konteks dunia nyata. Dalam suatu proses pembelajaran, penilaian autentik mengukur, memonitor dan menilai semua aspek hasil belajar (yang tercakup dalam domain kognitif, afektif, dan psikomotor), baik yang tampak sebagai hasil akhir dari suatu proses pembelajaran, maupun berupa perubahan dan perkembangan aktivitas, dan perolehan belajar selama proses pembelajaran di dalam kelas maupun diluar kelas.

Asesmen diperlukan untuk membantu para pendidik, orang tua, dan siswa dalam menentukan berbagai kegiatan instruksional, program penempatan (placement program), dan memonitor kemajuan siswa. Asesmen yang efektif dan akurat amatlah penting untuk meyakinkan bahwa peserta didik memiliki akses mengikuti suatu program instruksional yang memenuhi kebutuhan mereka.

Dari uraian tersebut di atas, asesmen autentik dapat diartikan sebagai penilaian yang meliputi proses dan hasil belajar siswa, sehingga dengan sistem penilaian ini berbagai cara penilaian bisa dilaksanakan dan berbagai aspek dari siswa dapat pula dinilai. Dengan cara ini hasil penilaian menjadi lebih lengkap karena segala usaha dan kemampuan yang dimiliki siswa (termasuk kognitif, afektif, dan psikomotorik) dapat terungkap dan bisa dihargai berupa nilai. Hasil penilaian menjadi sangat objektif sehingga mencerminkan kondisi siswa secara 
individu maupun kelompok. Bukankah penilaian dapat diartikan sebagai penghargaan kepada siswa atas segala usaha yang telah dilakukannya? Bukankah penilaian dapat dimanfaatkan untuk meningkatkan motivasi, partisipasi, kesiapan, aktivitas, dan kesadaran siswa dalam belajar, sehingga setiap saat terjadi peningkatan kualitas proses pembelajaran yang pada akhirnya bisa meningkatkan pula hasil belajar?

O’ Malley dan Pierce (1996: 4) menggunakan istilah asesmen autentic untuk mendeskripsikan format asesmen yang mencerminkan proses pembelajaran siswa, pencapaian, motivasi, dan sikap-sikap dalam aktivitas di dalam kelas yang relevan dengan tujuan instruksional. Penilaian autentik juga disebut dengan penilaian alternatif. Pelaksanaan penilaian autentik tidak lagi menggunakan format-format penilaian tradisional (multiple-choice, matching, true-false, dan paper and pencil test), tetapi menggunakan format yang memungkinkan siswa untuk menyelesaikan suatu tugas atau mendemonstrasikan suatu performasi dalam memecahkan suatu masalah.

Format penilaian autentik ini dapat berupa: a) tes yang menghadirkan benda atau kejadian asli ke hadapan siswa (hands-on penilaian), b) tugas (tugas keterampilan, tugas investigasi sederhana dan tugas investigasi terintegrasi), c) format rekaman kegiatan belajar siswa (misalnya: portfolio, interview, daftar cek, dsb).

Agar hasil belajar dapat diungkap secara menyeluruh, maka selain digunakan alat ukur tes objektif dan subjektif perlu dilengkapi dengan alat ukur yang dapat mengetahui kemampuan siswa dari aspek kerja ilmiah (keterampilan dan sikap ilmiah) dan seberapa baik siswa dapat menerapkan informasi pengetahuan yang diperolehnya.

Prinsip-prinsip penilaian autentik adalah sebagai berikut.

1. Proses penilaian harus merupakan bagian yang tak terpisahkan dari proses pembelajaran, bukan bagian terpisah dari proses pembelajaran (a part of, not apart from, instruction).

2. Penilaian harus mencerminkan masalah dunia nyata (real world problems), bukan masalah dunia sekolah (school work-kind of problems). 
3. Penilaian harus menggunakan berbagai ukuran, metode dan kriteria yang sesuai dengan karakteristik dan esensi pengalaman belajar.

4. Penilaian harus bersifat holistik yang mencakup semua aspek dari tujuan pembelajaran (kognitif, afektif, dan sensori-motorik). http://www.duniaguru.com - Portal Duniaguru Powered by Mambo Generated: 13 March, 2008, 18:09.

\section{Jenis-jenis Asesmen Autentik}

\section{Asesmen Kinerja (Performance Assessment)}

Asesmen kinerja (performance assessment) terdiri dari format- format asesmen di mana siswa menyusun suatu respon secara lisan maupun tertulis (Feuer dan Fulton, 1993; Herman, Aschbacher dan Winters, 1992). Asesmen ini mengajak siswa untuk melakukan tugas- tugas yang komplek dan bermakna yang berkaitan dengan pengetahuan, pembelajaran terkini, dan berbagai keterampilan yang relevan untuk menyelesaikan problem- problem yang realistik atau autentik (ibid, 1992:2).

Asesmen kinerja ini memerlukan penilaian guru terhadap respon siswa. Untuk membantu guru dalam melakukan penilaian yang akurat dan dapat dipercaya, diperlukan skala skor yang merujuk pada rubrik yang digunakan, di mana nilai numerik diasosiasikan dengan level unjuk kerja, seperti: angka 1 merujuk pada kemampuan tingkat dasar; 2 = tingkat sedang; $3=$ tingkat lanjut. Kriteria untuk masing- masing tingkat, hendaklah didefinisikan secara tepat berkaitan dengan kenyataan yang dilakukan siswa untuk mendemonstrasikan keterampilan dan kemahirannya pada level tertentu. Menurut Aschbacher (1991), salah satu karakteristik asesmen kinerja ini adalah bahwa kriteria dibuat dan diketahui secara umum. Dengan demikian, siswa juga dapat berpartisipasi dalam menyusun dan menggunakan kriteria dalam penilaian - diri (self-assesment) terhadap kemajuan yang mereka raih.

Menurut McMillan dalam Tanwey (2006:109), secara sederhana asesmen kinerja merupakan satu penilaian di mana guru mengamati dan membuat pertimbangan tentang demonstrasi siswa dalam hal kecakapan atau kompetensi 
dalam menghasilkan suatu produk. Asesmen kinerja adalah suatu prosedur yang menggunakan berbagai bentuk tugas-tugas untuk memperoleh informasi tentang apa dan sejauh mana penilaian kinerja ini menekankan pada kemampuan siswa untuk menggunakan pengetahuan dan kemampuan mereka untuk membuat hasil kerja mereka.

Asesmen kinerja dikembangkan untuk menilai kemampuan siswa dalam mendemonstrasikan pengetahuan dan keterampilannya pada berbagai situasi nyata dan konteks tertentu. Penilaian kinerja dapat dipersingkat atau diperluas dalam bentuk pertanyaan terbuka, membaca, menulis, proyek, proses, pemecahan masalah, tugas analisis, atau tugas lain yang memungkinkan siswa mendemonstrasikan kemampuannya dalam memenuhi tujuan belajar tertentu.

Menurut Luneta, et.al dalam Tanwey (2006: 110), penilaian kinerja dapat berbentuk (1) tes paper and pencil yang sasarannya adalah agar siswa dapat menampilkan karyanya, seperti desain alat, desain grafis, dsb, (2) tes identifikasi, yang bertujuan untuk mengukur kemampuan siswa dalam mengidentifikasi suatu hal, misalnya menemukan komponen yang rusak dari suatu benda, (3) tes simulasi, yang dilakukan tanpa menggunakan alat sesungguhnya dengan tujuan untuk menilai apakah seseorang telah menguasai keterampilan dengan bantuan peralatan tiruan atau berperaga seolah-olah menggunakan suatu alat, dan (4) tes unjuk kerja, yang dilakukan dengan alat seungguhnya dengan tujuan untuk mengetahui apakah siswa sudah menguasai atau terampil dalam menggunakan alat tersebut.

Asesmen kinerja ini bermanfaat baik bagi siswa, guru, dan orang tua. Asesmen kinerja memberikan kesempatan kepada siswa untuk berkompetensi dengan dirinya sendiri dan siswa memperoleh pemahaman yang nyata tentang apa yang mereka ketahui dan apa yang dapat mereka kerjakan. Di samping itu, asesmen kinerja memberikan informasi yang lebih baik dan lengkap bagi guru mengenai pemahaman, kesulitan, dan kemajuan belajar siswa. Asesmen kinerja juga membuat pembelajaran lebih relevan dengan dunia nyata dan dapat menyatu dengan program pembelajaran, sehingga asesmen kinerja dapat memberikan dukungan terhadap pembelajaran. 
Ada tiga alat atau instrumen untuk mengukur kinerja siswa, yaitu (1) daftar cek (checklist), (2) skala penilaian (rating-scale), dan (3) rubrik. Daftar cek dan skala penilaian digunakan untuk mengamati dan menilai kinerja siswa di luar situasi ujian, misalnya pada saat siswa melakukan praktikum, sebagai bagian dari kegiatan proses belajar mengajar. Sedangkan rubrik biasanya digunakan untuk menskor respon (jawaban) siswa terhadap pertanyaan terbuka (open-ended question). Rubrik memuat klasifikasi nilai yang dapat diberikan pada siswa sesuai dengan hasil kerja atau kinerja yang ditunjukkan siswa.

\section{Asesmen Portofolio (Portfolio Assesment)}

Penilaian portofolio merupakan sistem pengumpulan karya- karya siswa yang dianalisis untuk menunjukkan kemajuan siswa sesuai dengan tujuan instruksional (Valencia, 1991). Contoh- contoh portofolio meliputi: menulis sample, melukis, membaca logaritma, audio atu video-tape, dan komentar guru/ siswa pada kemajuan yang telah dicapai siswa. Salah satu fitur dalam penilaian portofolio ini adalah keterlibatan siswa dalam menyeleksi sample- sample karya mereka sendiri, untuk menunjukan perkembangan atau proses pembelajaran..

Portofolio merupakan jenis penilaian autentik yang sangat popular. Penilaian portofolio merupakan jenis penilaian yang relatif baru dalam pendidikan. Secara etimologi, portofolio (portfolio) bisa diartikan sebagai kumpulan (dokumen, berkas, bundel) bukti fisik tentang aktivitas. Jadi portofolio berarti kumpulan bukti fisik aktivitas kinerja (individu, kelompok, atau lembaga) sebagai data autentik yang dilakukan oleh yang bersangkutan. Asesmen portofolio merupakan salah satu cara penilaian terhadap kinerja dan hasil kerja, sehingga segala aktivitas yang dilakukan bisa dihargai dengan nilai. Asesmen portofolio menilai proses dan produk sehingga banyak digunakan karena tergolong ke dalam asesmen autentik-objektif-akurat.

Cara menilai portofolio biasanya menggunakan rubrik, yaitu penilaian dengan menggunakan skala bertingkat terhadap dokumen portofolio tersebut. Biasanya rubrik menggunakan skala bertingkat dengan memberikan nilai (skor) 1 untuk ketegori sangat kurang (SK), nilai 2 untuk kategori kurang (K), nilai 3 
untuk kategori cukup (C), nilai 4 untuk kategori baik (B), dan nilai 5 untuk kategori sangat baik (SB). Bisa pula dengan skala bertingkat menurut wilayah, misalkan untuk penilaian penghargaan yang diperoleh.

Dalam pengertian portofolio sebagai benda fisik, portofolio dapat memuat kumpulan hasil karya atau hasil belajar siswa, seperti hasil tes, tugas-tugas, catatan-catatan, ide-ide siswa, karangan siswa, rangkuman materi yang disajikan dalam berbagai sajian (tabel, diagram, dsb), karya seni, dan sebagainya. Heddens \& Speer dalam Tanwey (2006: 83), mengemukakan bahwa portofolio memuat sampel kerja siswa berupa proyek, laporan siswa, tulisan-tulisan siswa, hasil tes, dan sebagainya.

Untuk mengevaluasi siswa tidak cukup hanya dengan tes mengukur kemampuan akademik aspek kognitif saja, akan tetapi penilaian harus dilakukan secara objektif dan autentik meliputi berbagai aspek psikologis siswa. Guru harus mengakses siswa dengan berbagai cara dan berbagai segi aktivitas siswa.

\section{Asesmen Diri Siswa (Student Self Assessment)}

Asesmen diri siswa merupakan elemen kunci dalam asesmen autentik dan dalam pembelajaran yang diatur sendiri. Hal ini berarti meningkatkan keterlibatan siswa langsung dalam pembelajaran dan mengintegrasikan kemampuan kognitif dengan motivasi dan sikap terhadap pembelajaran. Untuk menjadi pebelajar yang mengatur sendiri, para siswa membuat pilihan- pilihan, menyeleksi aktivitasaktivitas pembelajaran serta merencanakan bagaimana memanfaatkan waktu dan sumber daya. Mereka memiliki kebebasan untuk memilih aktivitas yang menantang, ambil resiko sendiri, mempercepat pembelajaran sendiri, dan mencapai tujuan akhir yang dikendaki sendiri. Masing- masing siswa dapat berkolaborasi dengan temannya dengan saling bertukar ide, saling membantu bila diperlukan, dan saling mendukung. Menurut Paris dan Ayers (1994) pebelajar yang mengatur dirinya sendiri (self-regulated learners) memonitor unjuk kerja sendiri, dan mengevaluasi kemajuan dan pencapaiannya sendiri.

Penerapan asesmen autentik memerlukan keterlibatan guru lebih banyak daripada sekedar tes jawaban tunggal (single-answer test). Pengaturan waktu dan 
berbagai keterampilan bahasa diperlukan untuk mendesain dan menggunakan asesmen autentik ini. Sedangkan keputusan akhir penilaian diperlukan untuk menentukan kemajuan siswa dan kemajuan pembelajaran siswa. Adanya asesmen autentik ini, guru dituntut untuk memahami pola, kreasi dan prosedur penggunaannya, serta mengaitkan antara asesmen autentik ini dengan tujuan instruksionalnya dalam desain perencanaan pembelajaran.

\section{Tipe- Tipe Asesmen Autentik}

\section{a. Wawancara Lisan}

Kecakapan lisan harus dinilai secara teratur, terutama bagi siswa yang belum cukup dalam memahami instruksi bahasa, agar siswa juga mendapat nilai baik dalam asesmen tulisnya. Dalam wawancara lisan, siswa dapat merespon terhadap pertanyaan dengan topik- topik tertentu yang berkaitan dengan ilmu pengetahuan, aktivitas, minat dan hobby, atau lainnya. Sedangkan, guru dapat menggali informasi dari siswa dan menilai kecakapan siswa dalam merespon berbagai pertanyaan.

Keuntungan dari wawancara lisan ini adalah bahwa (1) kegiatan ini dapat dilakukan dalam konteks yang informal dan santai (relax); (2) untuk masingmasing siswa, wawancara dapat dilaksanakan pada beberapa hari berturut- turut, tidak harus dalam satu waktu; (3) Rekaman/ catatan pengamatan (observasi) dapat dilakukan dengan menggunakan 'panduan' wawancara (interview guide).

\section{b. Menulis Sampel/ Contoh}

Siswa diminta menuliskan contoh- contoh tulisan dengan tujuan yang berbeda- beda, seperti tulisan yang berbentuk narasi, argumentasi, atau paparan. Tulisan berbentuk narasi dapat berupa cerita pengalaman pribadi, puisi atau dongeng. Tulisan- tulisan lainnya dapat dibuat sesuai tujuan yang dikehendaki. Siswa dapat juga diminta untuk menulis surat, jurnal, esei, paper penelitian, atau berita koran. Atau, dapat juga siswa diminta membaca dengan topik tertentu, kemudian siswa menuliskan idenya untuk kemudian didiskusikan dalam kelompok, lalu tulisan tersebut diedit dan direvisi sehingga menghasilkan tulisan 
dengan tujuan tertentu. Dengan demikian dapat dinilai proses pembuatan tulisannya.

\section{c. Menceritakan kembali suatu teks atau kisah (cerita)}

Pada tipe asesmen ini, siswa membaca atau mendengarkan suatu teks kemudian menceritakan kembali sesuai ide pokoknya atau isi teks yang dikehendaki. Hal ini dikatakan asesmen autentik karena mencerminkan kegiatan nyata di dalam kelas di mana pencatatan dan pengumpulan data tentang kinerja setiap individu siswa dilakukan secara sistematis. Cara siswa merespon secara lisan dapat diukur dari bagaimana caranya melukiskan kejadian dalam cerita (struktur cerita), responnya terhadap cerita/ teks, serta kemahirannya dalam berbahasa.

Jadi, kelebihan dari penceritaan kembali teks/ cerita ini adalah (1) siswa dapat membuat laporan secara lisan; (2) dapat diberikan skor terhadap isi maupun komponen bahasanya; (3) dapat ditentukan pemahaman siswa terhadap bacaan, strategi membacanya, dan perkembangan kebahasaannya.

\section{d. Proyek atau Pameran}

Siswa dapat membuat sebuah proyek dengan topik tertentu, dan/ memamerkan karyanya. Pameran dapat berupa display (mempertontonkan hasil karya) atau menggunakan model yang sesuai dengan karya, permainan peran, simulasi, kreasi seni, grafik, tabel, dsb. Proyek ini dapat dilakukan baik secara individu maupun kelompok, dan dapat dipresentasikan secara lisan maupun tertulis. Jadi, guru dapat mengamati hasil presentasi lisan maupun tertulis sehingga dapat diamati juga keterampilan berpikir siswa (students' thinking skills). Adapun pemberian skor dapat dilakukan menggunakan skala rubrik maupun penilaian angka.

\section{e. Percobaan atau Demonstrasi}

Siswa dapat melakukan percobaan dengan menggunakan benda nyata atau dengan membuat ilustrasi cara kerja suatu benda. Percobaan atau demo ini dapat dipresentasikan secara lisan atau laporan tertulis yang mendeskripsikan langkah- 
langkah dan materi- materi yang diperlukan dalam percobaan, hipotesis yang diuji-cobakan, metode- metode yang digunakan, atau kesimpulan yang dihasilkan. Penilaian dilakukan pada pemahaman siswa terhadap konsep, penjelasan terhadap metode- metode ilmiah, dan/ bahasa yang digunakan dalam menjelaskannya.

\section{f. Respon}

Dalam tipe asesmen kinerja ini, siswa membaca atau mereview materi tekstual dan kemudian memberikan respon terhadap seperangkat pertanyaan terbuka- tertutup (open- ended questions) yang mendatangkan pemahaman dan pemikiran kritis. Penilaian terhadap siswa lebih difokuskan pada cara siswa 'menerapkan' informasi yang diterima, bukan pada seberapa banyak siswa mampu mengingat apa yang telah diajarkan oleh guru. Siswa dapat menggunakan grafik, peta, atau bagan tentang apa yang telah dibacanya dan memberikan komentar yang jelas terhadap inti bacaan atau esei yang mendiskusikan atau mengevaluasi bacaan tersebut. Dengan demikian, masing- masing siswa dapat merespon dengan cara yang bervariasi tergantung kemampuan dan kemahiran berbahasanya. Tipe pertanyaan seperti bagaimana cara memecahkan suatu masalah dan bagaimana kesimpulannya, dapat digunakan untuk merangsang respon siswa. Hal ini bersifat autentik karena siswa di dalam kelas menggunakan keterampilan berpikir dan mengungkapkan alasan di mana hasil pembelajaran ini dapat juga diterapkan dalam kehidupan nyata.

\section{g. Observasi Guru}

Pada tipe asesmen ini, guru dapat mengamati perhatian siswa terhadap suatu tugas, responnya terhadap aktivitas belajar yang diberikan, dan keterlibatannya dalam mengerjakan tugas kelompok dengan siswa lainnya. Untuk menentukan penilaian berdasarkan pengamatan ini, guru perlu membuat catatan atau merekam pengamatan ini secara sistematis dari waktu ke waktu dalam sebuah dokumen atau catatan pribadi (personal note) untuk mencatat perkembangan kinerja siswa, sehingga nantinya dapat dikomunikasikan dengan siswa, wali murid, atau guru lainnya. 


\section{h. Portofolio}

Portofolio merupakan kumpulan karya siswa yang dimaksudkan untuk menunjukkan kemajuan siswa dari waktu ke waktu. Karya- karya ini merupakan sampel dari beberapa karya siswa yang dapat diseleksi sendiri oleh siswa maupun oleh siswa dan guru yang menggambarkan pembelajaran terkait dengan tujuan instruksionalnya.

Portofolio dapat memberikan gambaran terhadap kinerja dan pembelajaran siswa, mengintegrasikan informasi dari berbagai sumber, dan menilai komitmen dan keterlibatan siswa.

\section{Kesimpulan}

Asesmen autentik yang telah dibahas di atas merupakan pengembangan model pengajaran dan pembelajaran. Model ini dapat merangsang siswa untuk aktif dalam merespon kegiatan pembelajaran bahasa dan memberikan tantangan bagi siswa untuk mengungkapkan pemahaman sekaligus penerapannya dalam kehidupan nyata. Tantangan bagi siswa ini sangat bermakna karena mereka dapat memberikan respon secara lisan maupun tertulis. Selain itu, hal tersebut juga bersifat fleksibel, yakni siswa dapat mendemonstrasikan kemampuan pengetahuan dan keterampilannya dengan cara yang bervariasi. Singkatnya, berbagai jenis asesmen autentik di atas, baik asesmen kinerja, asesmen portofolio, maupun asesmen diri, dapat meningkatkan kualitas pembelajaran yang bermanfaat bagi siswa.

\section{DAFTAR PUSTAKA}

Burhan Nurgiyantoro. 2001. Penilaian dalam Pengajaran Bahasa Indonesia. Yogyakarta: BPFE Yogyakarta.

Depdiknas. (2003). Assesmen Autentik, Materi Pelatihan Terintegrasi Kompetensi Guru Mata Pelajaran Biologi. Jakarta: Dikdasmen.

Feuer, M. J., dan K. Fulton. 1993. The many faces of performance assessment. Phi Delta Kappan 74 (6): 478

Herman, J.L., P.R. Aschbacher, dan L. Winters. 1992. A Practical Guide to 
Alternative Assessment. Alexandria, Va.: Association for Supervision and Curriculum Development.

Hibbard, M. (1995). Performance Assessment in the Science Classroom. New York: The McGraw-Hill Companies.

Johnson, D.W.\& Johnson. R.T.2002. Meaningful Assessment. Boston: Allyn and Bacon.

O’ Malley, J.M. dan Valdes Pierce, L. 1996. Authentic Assessment for English Language Learner: Practical Approaches for Teachers. USA: AddisonWesley Publishing Company, Inc.

Rusijono dan Bambang Yulianto.2008. Asesmen Pembelajaran: Bahan Pelatihan Program Continue Education bagi Guru SD di Lingkungan Dinas Kota Surabaya Tahun 2008. Surabaya:Universitas Negeri Surabaya.

Stiggins, R. J. 1991. Facing the challenges of a new era of educational assessment. Applied Measurement in Education 4 (4): 263- 272

Yulianto, Bambang.2005. Pembelajaran Kontektual dalam Mata Kuliah Bahasa Indonesia Keilmuan. Makalah Disampaikan pada Seminar Bahasa Indonesia Keilmuan di ITS Tanggal 28 Juli 2005, Surabaya: MKU ITS. 